\title{
DAN PIENAAR GUN PARK LAUNCHES MUSEUM INTO 21ST CENTURY
}

BY

\section{DR S. MONICK*}

Note: Unless where otherwise stated, all photographs are by the author.

On 14 February 1992 there occurred the official opening of the Dan Pienaar Gun Park at the South African National Museum of Military History. The Gun Park is a newly completed exhibition area created by roofing and repairing the central courtyard between the exhibition's main halls. Lt $G e n G$ L Meiring, SSA, SD, officially opened the Dan Pienaar Gun Park. The statue of Maj Gen D H ('Dan') Pienaar was officially unveiled by his widow (now Mrs Norma Seuffert). Maj Gen Pienaar's children, Fay, Barry and Nelia, were also present, in addition to a very wide representation of the Pienaar family.
Museum of Military History is a foremost custodian of artillery pieces, which encapsulate the history of gunnery. At the heart of the project is the highly original fusion of two - ostensibly disparate - approaches. The first is the application of the very latest developments in building technology; and, secondly, the reconstruction of the atmosphere of the World War I era. Both pivot, to reiterate, upon the preservation of 9 extremely valuable guns, evocative of central themes in the history of artillery.

Within this context, it should be noted that the project embodies a certain

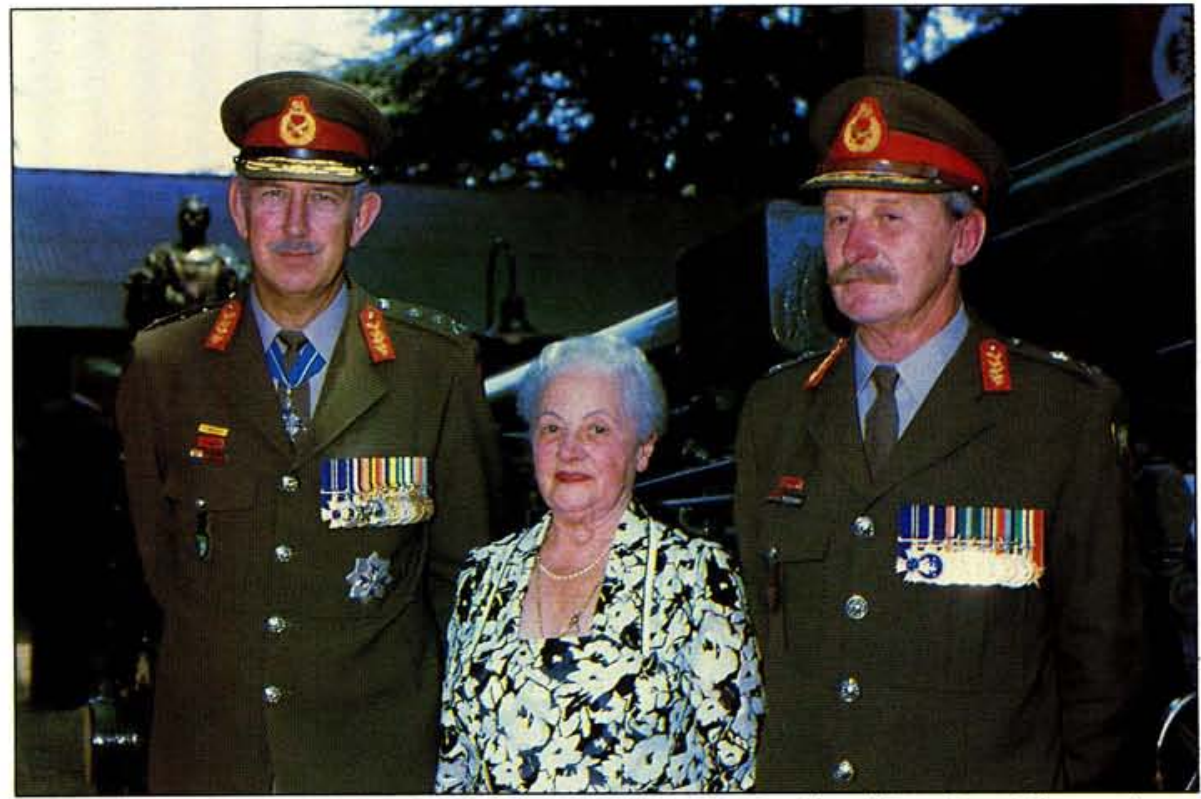

Left to right: Lt Gen G.L. Meiring, Mrs Norma Seuffert (Gen Dan Pienaar's widow) and Maj Gen Philip Pretorius. Photo: Paratus

The occasion marked the completion of a project which is founded upon several unique and novel approaches to the concept of a living museum; centred upon the preservation and conservation of several priceless guns. As is well known, the SA National degree of continuity with an article previously published in Militaria, entitled Silent voices of time; a selective study of the sculpture of the South African National Museum of Military History. ${ }^{1}$ Two of the sculptural pieces discussed in that article - the bust of

'Monick, S. Silent voices of time: a selective study of the sculpture of the South African National Museum of Military History. Militaria, 21/4, 1991, pp 15-33. 
Wilhelm II and the statue of Maj Gen D $\mathrm{H}$ Pienaar - occupy prominent places in the new Gun Park.

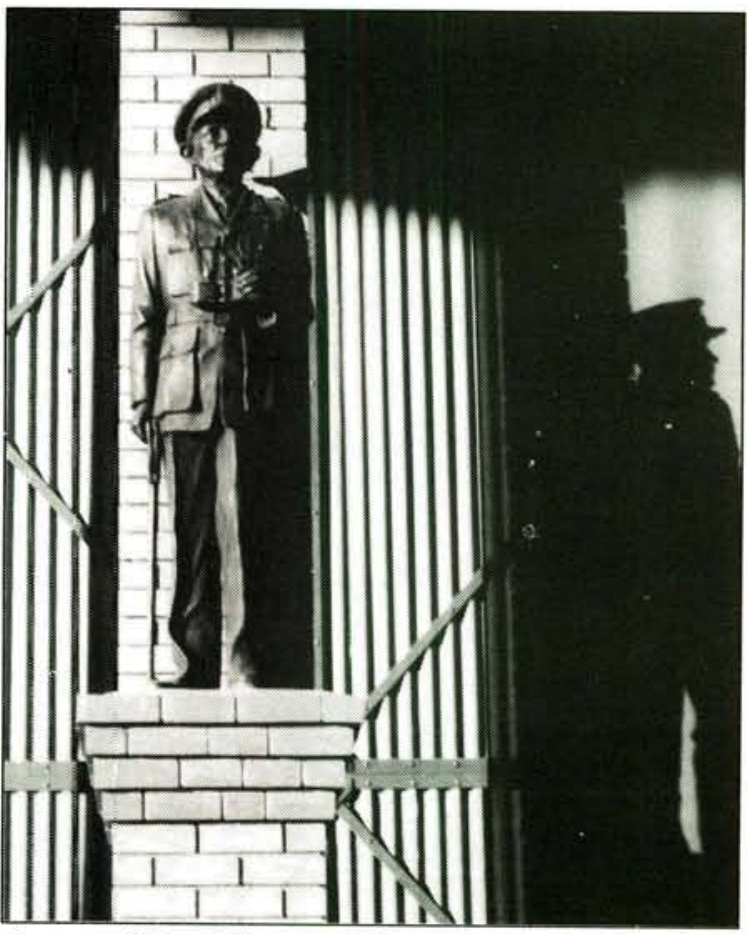

Statue of Dan Pienaar. The photoghaph was taken in the early morning light, which has cast a long shadow upon an adjoining banner

The interaction between the display of the guns and the evocation of the society which experienced the Great War, projects a most profound theme in the military history of the 20 th
Century. For European society was effectively destroyed on the Western and Eastern Fronts in World War I; in terms not only of the irrevocable and far reaching loss of manpower, but also with regard to political structures, values and ideals. A major factor in the annihilation of that political and social world was rapid firing breech loading artillery which, together with machine guns and gas, was instrumental in the destruction of an entire generation. The barrages of the heavy artillery indelibly impressed itself upon the mind of that generation, fused with the image of barbed wire. In his renowned poem. Anthem for doomed youth, Wilfred Owen (one of the most distinguished poets of the Western Front, which claimed his life precisely one week prior to the end of hostilities), speaks of 'the monstrous anger of the guns'. He suggests the dominant impress of artillery fire upon all those who endured the ordeal of being constantly subjected to the terrible rain of shells (whether helplessly enduring this fire upon their trenches, or being thrust into the maelstrom of artillery fire whilst assaulting the opposing lines of trenches).

The main driving force and shaping influence in the conception and deve-

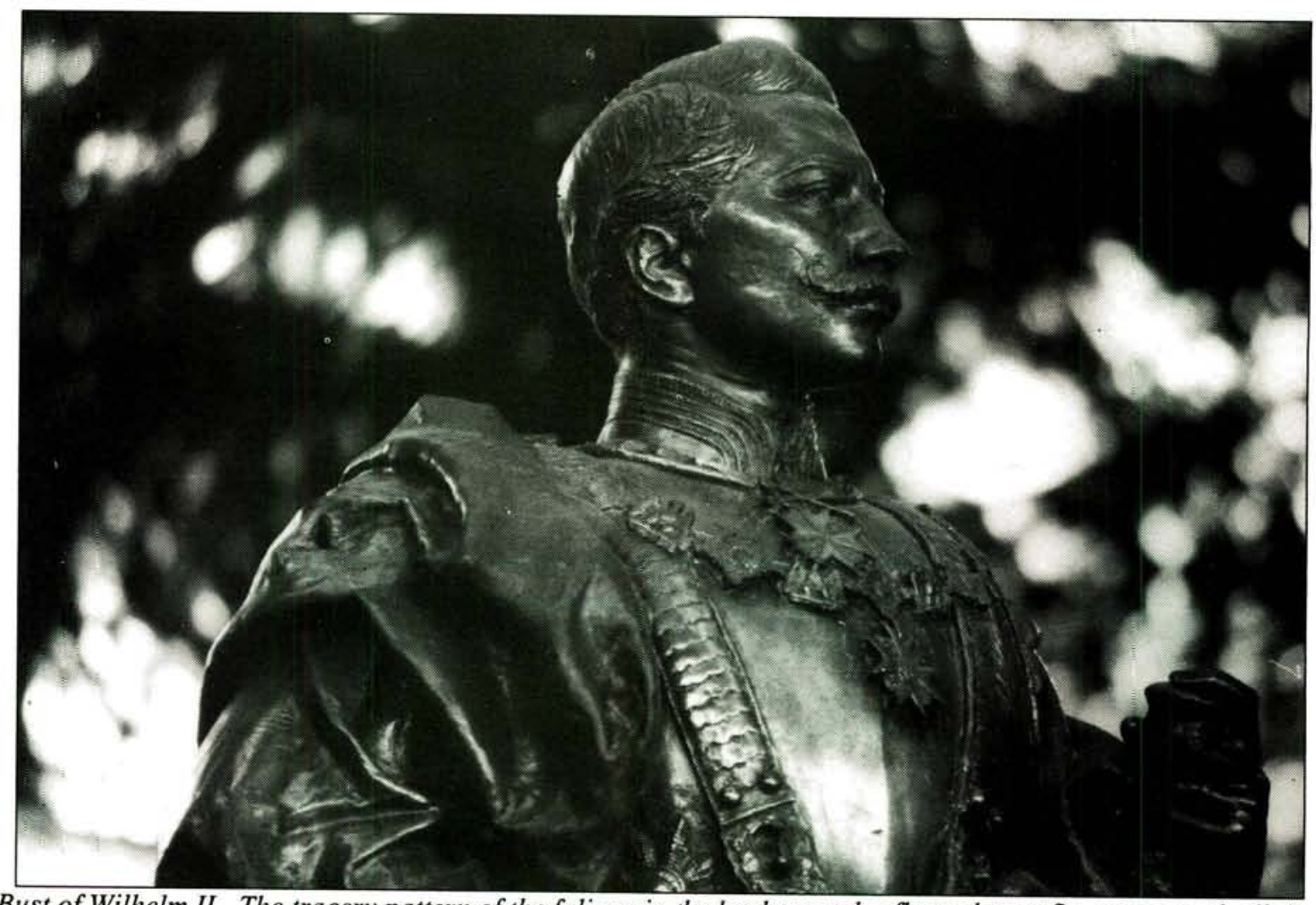

Bust of Wilhelm II. The tracery pattern of the foliage in the background reflects the roof's access to the light. 
lopment of the gun park is Maj Gen Philip Pretorius, SD,SM. Maj Gen Pretorius was appointed Director of the South African National Museum of Military History in 1988. His dominant impact upon the Museum's image and appearance, subsequent to his appointment, is most manifest. The total reconstruction of the Jan Smuts display and development of the side panels, both within the Brink Hall, are two obvious illustrations. His dynamic approach has also been illustrated in the very considerable assistance which the Museum has proffered to the Delville Wood Museum in France.

He has remained a member of the artillery corps throughout his long and distinguished military career; commencing his service in 10 Battery of 4 Field Artillery (as it was then termed, subsequently redesignated 4 Artillery Regiment which, together with 14 Artillery Regiment, forms 10 Artillery Brigade). Maj Gen Pretorius is, of course, widely known within the Gunners' Association, having served as informed the author in a taped conversation of 16 October 1991 - to be the most telling arm in military history (and, more specifically, that of South Africa.) Maj Gen Pienaar was preeminently an artilleryman, and his outstanding successes in the Abyssinian and North African campaigns (successively commanding 1 South African Infantry Brigade in Abyssinia and North Africa and, subsequent to March 1942, succeeding Lt Gen Brink as commander of 1 South African Infantry Division), pivoted upon the most skilful deployment of his guns; especially the 25-pr. He naturally became a focus of Maj Gen Pretorius's admiration and the latter considered that, in view of $\mathrm{Maj}$ Gen Pienaar's role as an outstanding gunner, the gun park should commemorate and revere the memory of this most distinguished South African commander.

The Gunners' Association is also represented in this project by Col L Human, JCD, who served as the Director's technical adviser and was in charge of

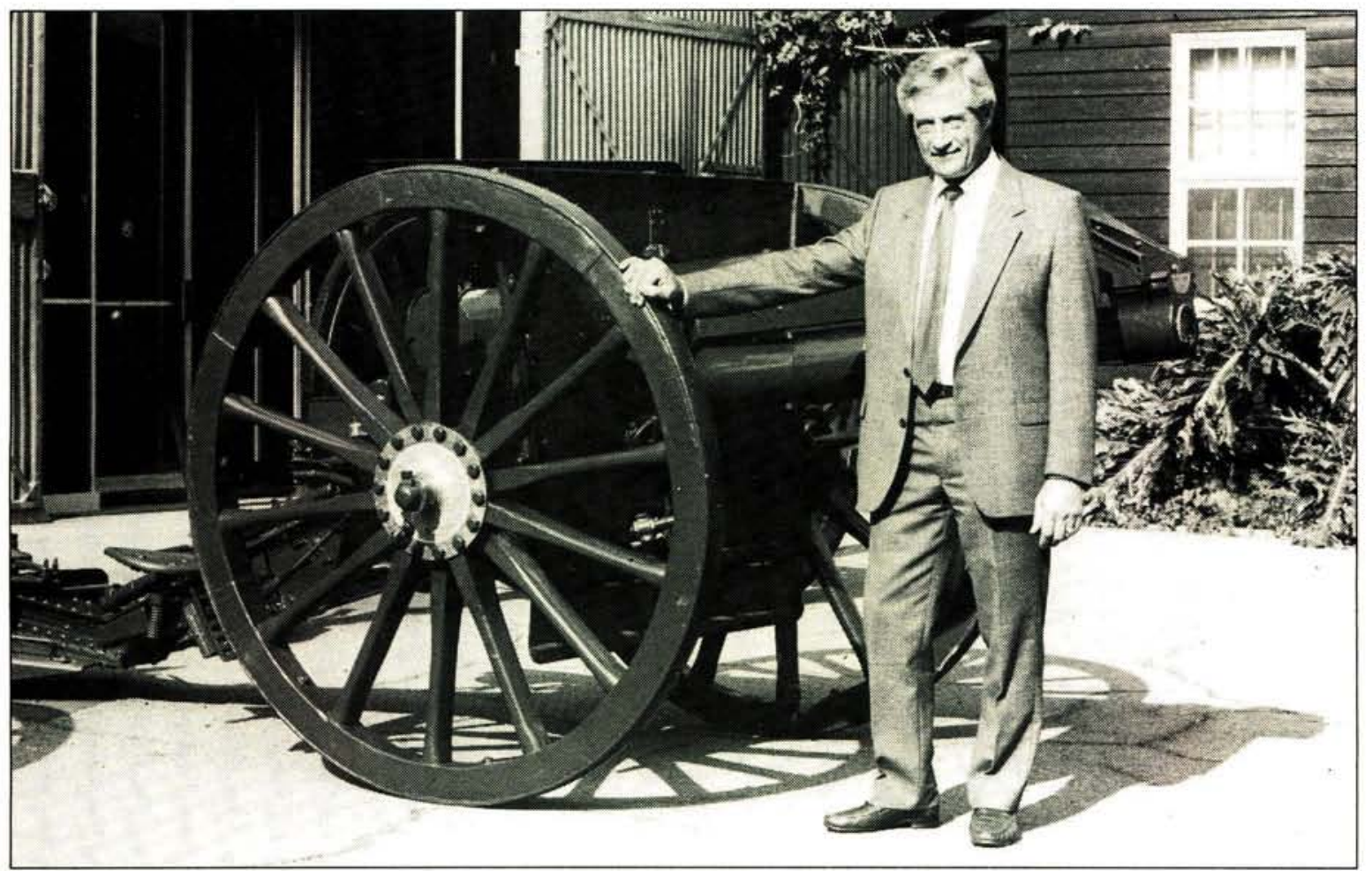

Col L. Human, JCD, standing next to 15 pr Mark IV field gun. The photograph was taken before the gun park was constructed.

National President of that body. Whilst a cadet at the Military College (following his graduation from the University of the Witwatersiand with a BA degree), he rapidly developed a fascination for artillery and considers it - he the physical execution of the scheme. Col Human joined the Museum in 1991. following three years service on its Board of Trustees. He is the head of the Technical and Art Departments. His central role in the development of 
the Dan Pienaar Gun Park fuses and fully utilizes both his professional and military careers. He graduated from the University of the Witwatersrand with a B Sc degree in electrical engineering, and also from the University of South Africa (UNISA) with a Master in Business Leadership (MBL) degree. His military career has been that of a gunner. He served as Officer Commanding an anti-aircraft regiment (ROV) during the period 1973-1982; as well as Deputy Director of Anti-Aircraft for the Citizen Force and Staff Officer (SO) Anti-Aircraft with 8 Armoured Division. When he retired from the Citizen Force he had contributed no less than 43 years service. Col Human obviously possesses a deep and closely informed interest in artillery. As in the case of Maj Gen Pretorius, he is widely known to members of the Gunners' Association, serving as Deputy National Chairman.

At this point, it is deemed apposite to elucidate the salient features of the gun park, several of which have been referred to above.

\section{THE ROOFING}

It will be noted, in the course of this article, that the term 'roofing' is employed, as opposed to 'ceiling'. The latter word is, in actual fact, a misnomer, within the context of the Military History Museum's new gun park. The term 'ceiling' immediately suggests a firm, solid plane, or area, which, superimposed upon the walls, seals the building from the exterior natural environment. However, the roofing which spans the Brink and Adler Halls consists in part of transluscent glass panels, which will permit the visitor to view the sky above; the glass panels being juxtaposed with those of metal. A vast amount of light and air is thus admitted to the courtyard below.

Maj Gen Pretorius first conceived of the idea of the unique covering of the gun park whilst visiting the Imperial War Museum in London, in 1990. This British museum has covered a courtyard situated between two buildings, creating a massive light area in the process. The roofing which covers the new gun park of the South African
National Museum of Military History encompasses some 1000 square metres of space (in effect adding a new exhibition hall) and spans the area between the George Brink and Fritz Adler exhibition halls. The roof is some 12-15 metres in height, and exceeds the height of the two halls which it links by approximately one metre. A major revolutionary aspect of the design is that it rests on six gigantic concrete, brick lined, steel reinforced pillars (three on each side, but none within the interior area of the space covered). The covering thus appears to be suspended in space, without visible support (although this support is, of course, provided by the six pillars). The metal panels of the roofing are prevarnished, sky blue in colour. Some 15\% of its total surface is transluscent, thus admitting light.

\section{THE COURTYARD}

What does this futuristic roofing cover? The answer to this question introduces the second forward-looking concept involved in the gun park. The courtyard has been totally re-constructed. Maj Gen Pretorius derived the idea of the courtyard from the Union Buildings in Pretoria (designed by Sir Herbert Baker), characterized by its pre-1914 period piece round stairwells; although, in the Museum's instance, the paving is of brick, and not of sandstone. The courtyard of the Dan Pienaar Gun Park incorporates two levels; an upper level in the vicinity of the existing office block, and a lower level adjacent to the administration building. The interior thus reproduces the form of an amphitheatre; ideal for lectures, book launches, dramatic performances and social functions such as Remembrance Day services. The gun park can thus be used to accommodate this great variety of demands made upon the courtyard area.

The entrance to the courtyard from the grounds has been expanded, and the widened archway thereby created leads into the gun park. Spotlights, fitted to the facing walls of the flanking exhibition halls, will, at night, focus upon the guns and the other exhibits contained within the gun park. 
From the roofing there is suspended the flags of the Union of South Africa and Imperial Germany, hovering above the guns of those nation's respective forces. The future development of the gun park envisages that panels, also suspended from the transluscent covering, will contain information relating to the pivotal figure of Maj Gen Pienaar; the socio-political background of European society on the eve of World War I; the historical development of artillery; in addition to other themes embodied by the exhibits in the courtyard. As intimated above, the courtyard also features a recently restored bust of Kaiser Wilhelm II, originally captured by South African forces in Windoek in 1915. This bust is most appositely placed within the context of the historical reconstruction contained within the courtyard. As intimated in a previous article in Militaria, ${ }^{2}$ the Kaiser exerted a most dominant impression upon his contemporaries in the decades which preceded the outbreak of World War I; and was an instrumental figure in the creation of that overheated international climate (characterized by an arms race pivoting upon artillery and naval expansion) which ultimately gave birth to the holocaust of 1914 .

Certainly, the guns, flags and bust of the German Kaiser will combine with the spotlight to create an unforgettable experience; in which the visitor, bathed in the light streaming through the transluscent roof, will imagine himself/herself transported in time to the World War I era.

The project accommodates several important priorities of the Military History Museum. The first is the thematic and dramatic display of eight of its most important guns. The second is the relocation of the statue of Maj Gen Pienaar (formerly situated within the Museum grounds) to a context fitting to this most distinguished South African soldier.

The revolutionary development of the area between the two exhibition halls represents the first phase of a five year plan, involving the phased introduction of additional facilities. The essential feature of this development plan is that it will be financed entirely from Museum generated own funds. No

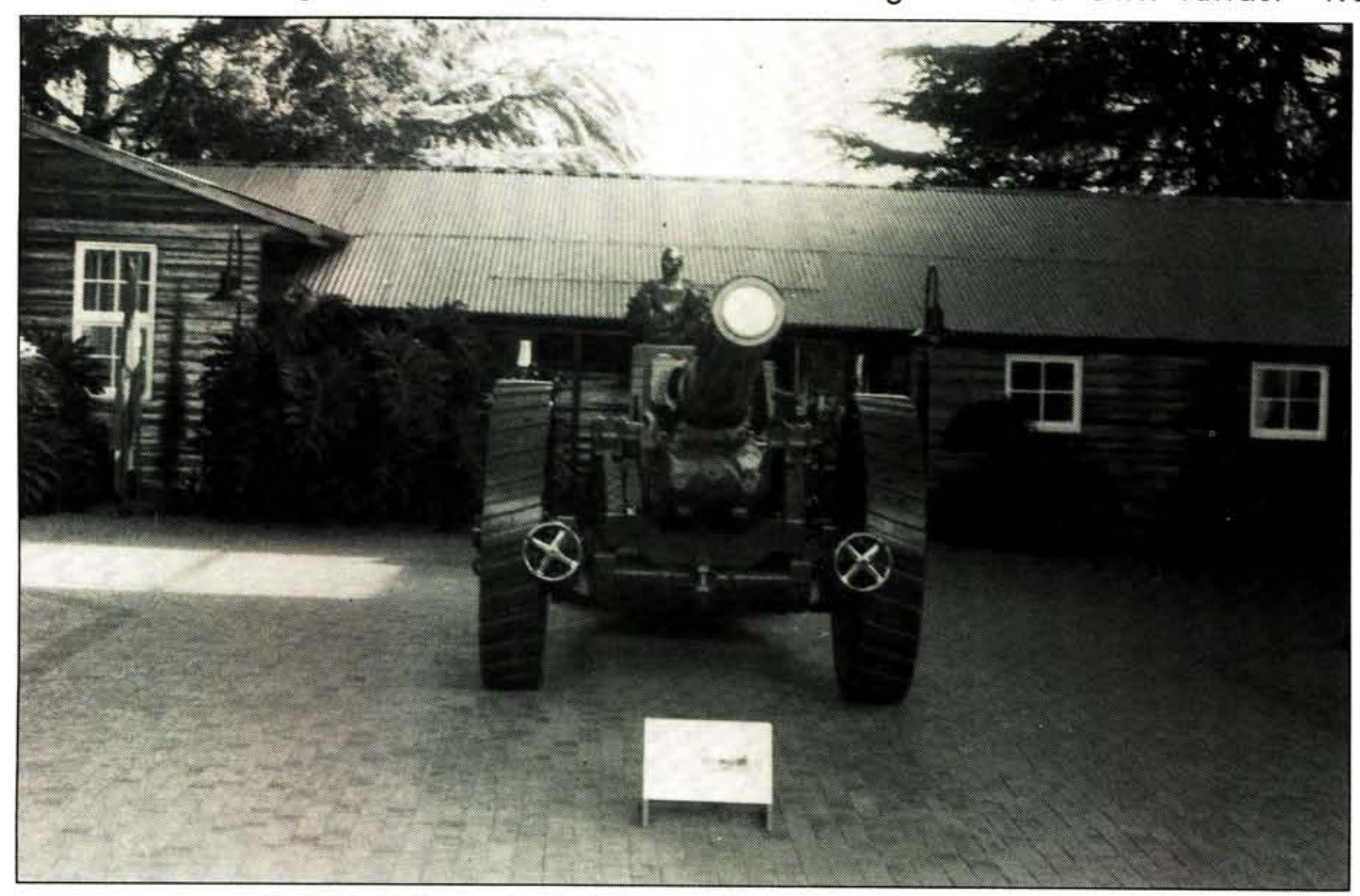

6 - in Mk XIX gun. In the background is seen the bust of Wilhelm II.

${ }^{2}$ Monick, S. Silent voices of time: a selective study of the sculpture of the South African National Museum of Military History. Militaria, 21/4, 1991. 
state assistance whatsoever is envisaged at this point in time.

\section{THE GUNS}

The three central features of the gun park are the 9 guns exhibited, the statue of Maj Gen Pienaar and the bust of Wilhelm II. The latter two exhibits have been discussed in detail in a previous issue of Militaria ${ }^{3}$. This article will, accordingly, focus upon the guns.

\section{GERMAN ARTILLERY}

(i) A German $7.5 \mathrm{~cm}(75 \mathrm{~mm})$ mountain gun, Model 08. It was captured in German South West Africa by troops of the Union Defence Forces, and then used against German forces in East Africa, during World War I.

The gun was designed by Herr Erhardt, of the Rheinesche Metallwaaren und Maschinenfabriek of Dusseldorf. He was a prominent designer of guns at the dawn of the present century, and designed the first 'long recoil' gun of the British Army; viz the 15-pr QF. There were no mountain artillery units in the German Army of the pre-World War I period. In 1904 Erhard produced his design of a mountain gun. It represented a seminal landmark in the development of artillery, as it incorporated the facility of 'variable recoil'; ie long recoil at low angles of projection, and short recoil at high. It is possible that this gun represents the very first field artillery possessing variable recoil, a normal feature of modern guns. The gun was first produced in several versions; viz in 1904 and 1906. The piece is distinguished by its folding trail. Whilst mountain guns demanded a short trail (for mobility and towing purposes, and also to achieve high elevation) a long trail was necessitated by the demands of stability on firing. Both demands were met by Erhardt through his telescopic trail. The gun was principally employed in the German colonies, including South West Africa. Some guns were sold to the Portuguese for use in Angola in 1906; and others employed by the Dutch in the Far East.

(ii) Two German $150 \mathrm{~mm}$ howitzers. The correct designation of these guns is the $15 \mathrm{~cm}(150 \mathrm{~mm}) \mathrm{sFHO} 2 \mathrm{Howitzer}$. Designed and first manufactured by the Krupp works in 1902, this heavy howitzer was an improved version of the earlier $15 \mathrm{~cm}$ sFH93 employed against South African troops during the South West African campaign of 19141915. Together with the $15 \mathrm{~cm}$ (150 $\mathrm{mm}$ ) sFH 13 (long) and the sFH13/02, the two pieces exhibited represent one of the standard German howitzers employed throughout the horrendous war on the Western Front. The guns displayed were manufactured in 1917 and were captured on the Western Front during the following year. The British Government despatched them to South Africa, as war trophies, following the end of World War I; and for some years the guns stood in front of the Johannesburg City Hall until the Johannesburg City Council presented them to the South African National War Museum (as the Military History Museum was then named) in 1952. Both howitzers are painted in the camouflage colours adopted circa 1917.

(iii) An $8 \mathrm{~cm}(80 \mathrm{~mm})$ gun. Originally used by Austro-Hungarian forces in World War I, it served Mussolini's artillery in World War II. The weapon was manufactured by Skoda, at its armaments works in Pilsen (now located in Czechoslovakia). In 1918 a considerable number of these guns were captured by the Italians, who thereupon absorbed them into their own gunnery arm; and, lacking any major modifications, the guns were utilized throughout the inter-war years; to be later deployed in the Abyssinian and North African campaigns during World War II. The gun exhibited was captured by South African forces at Mega (February 1941) in the former theatre of war; and many more were taken in the Western Desert. The gun exhibited at the Museum was manufactured in 1917. It was originally designed as a horse-drawn gun, and could be broken down into three loads: barrel and recoil mechanism; carriage; and

${ }^{3}$ Monick, S. Silent voices of time: a selective study of the sculpture of the South African National Museum of Military History. Militaria, 21/4, pp 19-20,26-27. 
wheels and shield. The piece has been repainted in its original World War I colours.

(iv) A German $7,7 \mathrm{~cm}(77 \mathrm{~mm})$ gun, used by the German artillery, in German South West Africa during World War I. The official nomenclature of this gun is the $7.7 \mathrm{~cm}(77 \mathrm{~mm})$ Krupp Field Gun M96 (new type). This weapon was developed in 1904, and, at the outset of the Great War, became the standard field gun of the German Army. The gun, together with an identical model, stood outside the supreme Court in Johannesburg from the end of World War I until 1983, when it was donated to the South African National Museum of Military History.

It is extremely significant that the 7,7 $\mathrm{cm}(77 \mathrm{~mm})$ gun, discussed immediately above, bears the legend, 'Ultima ratio regis' ('the last argument of kings'), above which the arms of the Hohenzollern dynasty are impressed. Louis XV ordered the motto to be impressed upon all artillery pieces, underscoring its pre-eminence in war. In historical terms, it is especially apposite that this Latin legend should be juxtaposed with the arms of the Prussian ruling house (the Hohenzollerns); Germany having been unified under the leadership of the Hohenzollern dynasty, and thus 'Prussianized' in the process (exemplifying Bismarck's maxim of 'blood and iron'). The German state which emerged following the Franco-Prussian War of 1870 1871 was underpinned by the exaltation of military power, personified in the figure of Kaiser Wilhelm II. The presence of the Prussian Royal Arms upon both the $77 \mathrm{~mm}$ gun and also the $75 \mathrm{~mm}$ Model 08 thus symbolize the overriding impress of the German military establishment upon Wilhelmine Germany.

The traditional Prussian 'junker' class (whose traditions were essentially of a militaristic character) provided the social and military elite and dominated positions of power within the new state. The military aristocracy provided virtually all the officers of the professional army; not only of the Guards but for most cavalry and infantry regiments also, allowing a mere sprink- ling of recruits from the new middle classes to infiltrate the reserve. Above all, the junker class monopolized the three personal secretariats (or Cabinets); one for the Army, one for the Navy and one Civil, which discharged the supreme executive responsibilities of Kaiser Wilhelm II. The armed forces lay beyond the power of the civil constitution in all matters save budgetary control, the senior officers (and, indeed, officers of whatever rank) appointed by, and responsible to, the Commander-in-Chief; ie the Kaiser. A commission in the Army Reserve was an essential badge of respectability for a business or professional man.

The German field guns exhibited in the gun park possess a specific, as well as generalized symbolic value. For the focus of German military power was directed upon artillery. It has with justice been said that rapid firing breech loading artillery was the preWorld War I counterpart of thermonuclear weapons, and cast steel that of nuclear fission.

The heart of Germany's economic power resided in the Ruhr, in actual fact the Ruhrgebelt, the environs of the Ruhr waterway. In this basin the German mine as much coal as the remainder of the continent combined, and produce more fine steel. Some 15 cities are encompassed by the Ruhr, the heart of which has been Essen, since the last quarter of the 19th Century. The area forms Europe's prime source of coke - pure carbon (acquired by 'cooking' coal to extract its gases) - a spongy, brittle coke that is indispensable for the conversion of iron into steel. The Ruhr was the pivot of a relationship which has been defined (to quote a phrase that became popular during the 1970s) as the militaryindustrial complex. During the final quarter of the 19th Century the Ruhr became dominated by fewer than a dozen Schlotbarone ('smoke stack barons'); ie industrial leaders, the founders of dynasties (foremost among which was the Krupp concern, which recurs in the discussion of the German pieces above.) This new social force displaced the declining feudal aristocracy. The energies of this vast concentration of economic, social and 
political power were heavily orientated towards armaments production. Indeed, it was this powerhouse - centred on Krupp - which produced the artillery which had crushed France in 1870 1871. Thenceforth, until 1945, the Ruhr underpinned the military power of both the Second and Third Reichs. The artillery pieces discussed above thus encapsulate vital themes in the political-military history of Germany during the period $1870-1945$.

\section{ALLIED ARTILLERY}

(v) A British QF (Quick Firing) 13-pr field gun. This gun was the staple arm of the Royal Horse Artillery during the decade preceding the outbreak of World War I, and during that War itself. in the case of the $7,5 \mathrm{~cm}(75 \mathrm{~mm})$ mountain gun, discussed above. this piece represents a milestone in artillery development; in this case with regard to the Royal Horse Artillery. For the very first time in the Royal Horse Artillery's armament, a bullet proof shield was fitted. This development was witness to the terrible vulnerability of horse gunners to the new magazine rifles introduced during the last decade of the 19th Century; gun detachments being exposed to accurate and rapid small arms fire at ranges of 1800 metres. To reiterate, it was the gun of the Royal Horse Artillery, and was employed throughout the Great War of 1914-1918, firing some 1,5 million shells in the course of that conflict. It continued in service until the years immediately preceding World War II, being superseded by the 25-pr. South African artillerymen used this gun in the South West African and East African

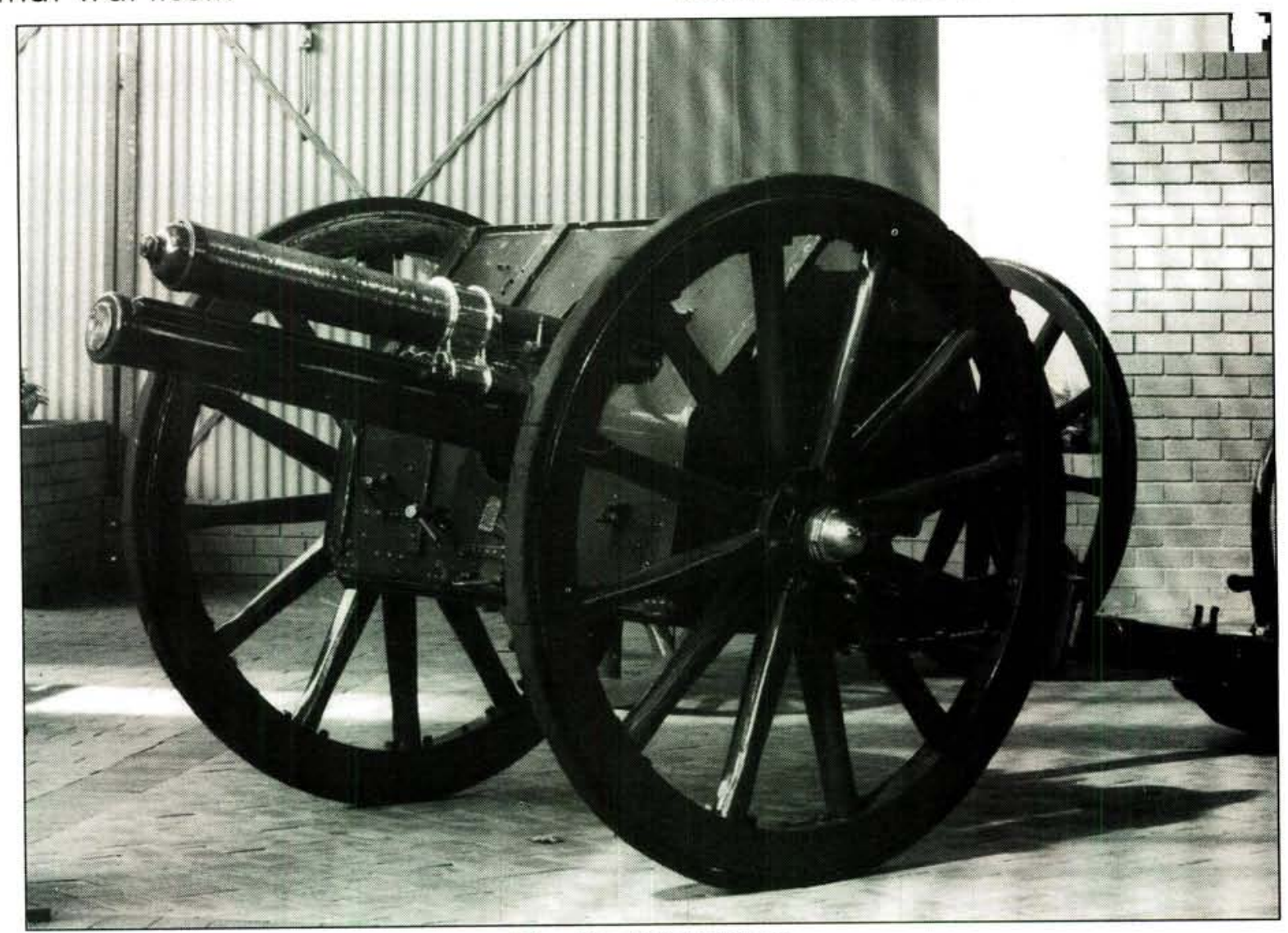

13 pr Mark IV Field gun

The QF 13-pr's design was finalized in 1903 and taken into service in 1904 . Its introduction embodied the recognition that the British 12 and 15-pr guns, employed during the Anglo-Boer War of 1899-1902, were inferior in many respects to the French Creusot and Krupp guns deployed by the Boers. As campaigns of World War I. The gun exhibited in the Military History Museum is mounted on a light, robust pole carriage, and was manufactured in 1913.

It should be noted that this weapon is not totally obsolete, as it is fired by the 
King's Troop of the Royal Horse Artillery on the British Sovereign's birthday and other ceremonial occasions.

(vi) A British BLC 15-pr Mark IV field gun. The BL 15-pr was the standard British field gun during the AngloBoer War of 1899-1902, and probably experienced more extensive modifications and changes of name than any other gun in British service. The breech loading converted field gun exhibited is the end product of all these. 15-prs of various marks were still in service and, as the production of the $18-\mathrm{pr}$ was initially slow, it was decided to up-date and modify the later models of 15-prs and retain them in service until all could be replaced. Trials were undertaken in 1907 and 1908, and the BLC 15-pr was introduced for service as a 'stop gap' gun in 1909; being issued to British Territorial Army batteries and to various colonial artillery units. These guns remained in use until approximately the end of 1915; at which point in time all had been replaced by 18 -prs.

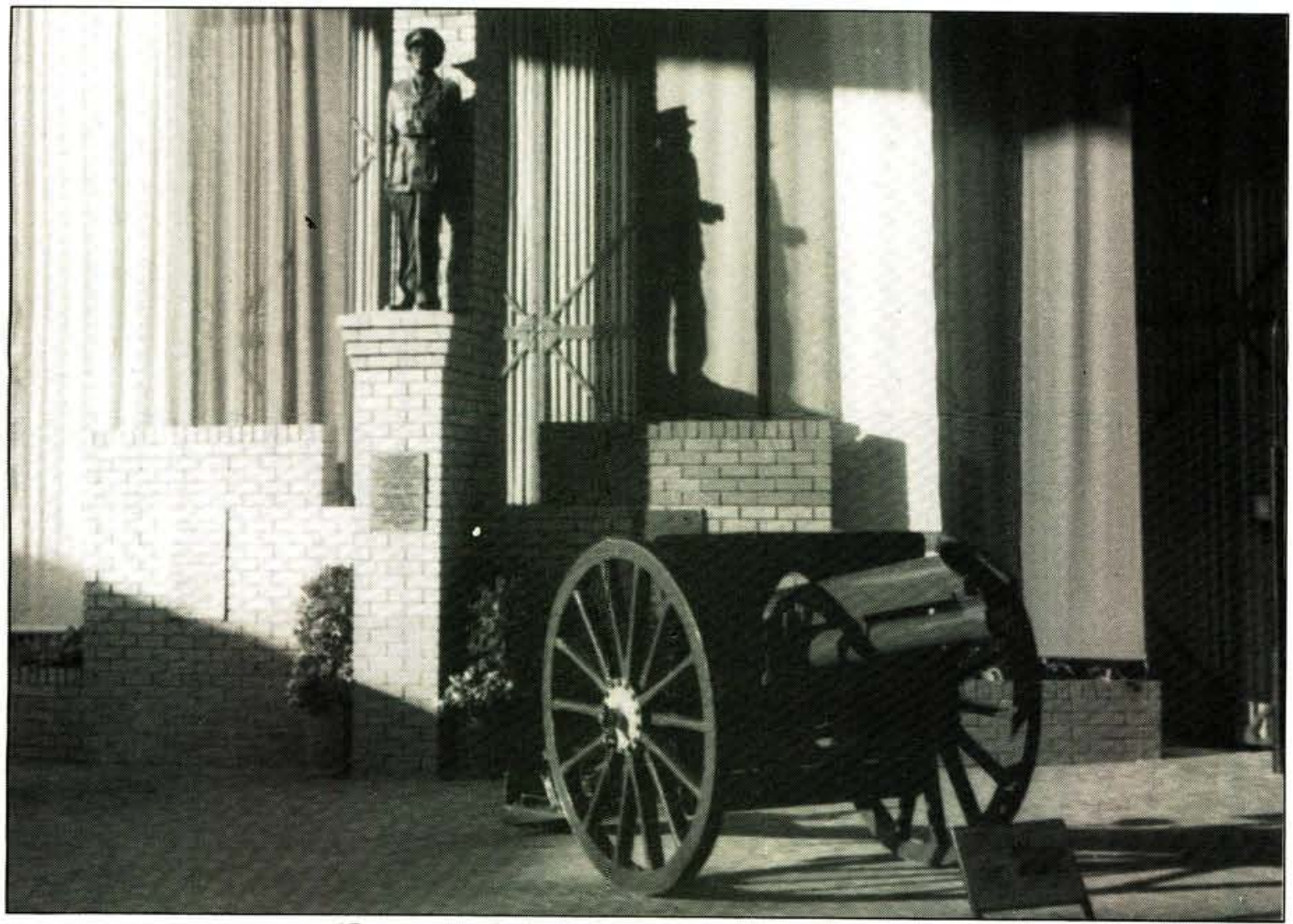

$15 \mathrm{pr}$ gun at the foot of the statue of Maj Gen Pienaar

The gun was originally produced in 1883 as the BL 12-pr of $7 \mathrm{cwt}$, for use by the Royal Horse Artillery. In 1895 it was modified to enable it to fire a $14 \mathrm{lb}$ $(6,35 \mathrm{~kg})$ shell. It was then redesignated as the BL $15 \mathrm{pr}$ Mark I and issued to the Royal Field Artillery; the horse artillery being issued with the new, and lighter, 12-pr gun. In 1899 the 15-pr Mark II gun appeared. It was fitted with a new and improved 12-pr breech mechanism which remained interchangeable between this type and all subsequent marks of 15-pr. The BLC 15-pr Mark IV is fitted with this mechanism. When the QF 18-pr was accepted as the standard British field gun in 1904, a considerable number of
A few BLC 15-prs were used by South African artillerymen during the South West African campaign of 1915. At least two of these guns underwent yet further modification in the Salt River Railway workshops in Cape Town, where they were fitted with special high angle mountings in November 1914 and despatched to South West Africa, as anti-aircraft guns. Nicknamed 'Skinny Liz', they were the first South African anti-aircraft guns.

(vii) A British QF 18-pr field gun; the staple armament of the British field artillery during World War I and also that of the South African artillery during the period 1918-1942. This gun is 
similar in both design and construction to the 13-pr field gun discussed above. This slightly heavier field gun entered British service in 1904. As in the case of the 13-pr gun, it embodied the recognition of the inferiority of the British 15 pr gun to the Creusot and Krupp field guns used by the Boers. By 1914, 18-prs had replaced the majority of 15-pr guns in service with the Royal Artillery and the process had been completed by the end of 1915. Several 18-prs had been sent to South Africa during the course of the South West African campaign. South African gunners used this piece during the subsequent campaigns in East Africa, North Africa and Palestine. In 1916 the Mark II carriage, fitted with a larger cradle and a hydro-pneumatic recoil system, made its appearance. The gun exhibited at the Museum is mounted on this carriage. By the end of 1918 these guns had fired over 100000 shells. The gun enjoyed a long life, being the subject of further modifications during the 1930s. It was deployed extensively by South African artillery in the Abyssinian campaign of 1940-1941.

(viii) BL 6-in Mark XIX gun: The 6-in gun originated in a British naval piece of $Q F$ 4,7-in calibre, mounted on a specially designed field carriage created by Capt Percy Scott in the Royal Naval dockyards at Simonstown, during the early phase of the Anglo-Boer War (1899-1902).

Three such guns were used during this war. Some were sent to France in 1915 in response to the urgent need for heavy artillery. As the 'Scott carriage' limited the gun's elevation and range, a new carriage facilitating greater elevation was designed. However, this equipment weighed in excess of 25 tons and was too heavy. It was superseded in 1917 by a new 6-in Mark XIX wire-wound gun mounted on a slightly modified 8-in howitzer carriage. The new weapon weighed little more than 10 tons. It possessed a range of 17820 metres (firing a streamlined shell). By the end of World War $I$, in 1918, 108 Mark XIX guns were in service on the Western Front.

At the close of hostilities four of these weapons were sent to South Africa. As the outbreak of World War II loomed the Union Government realized that two of South Africa's major ports - East London and Port Elizabeth - were totally devoid of coastal artillery. Accordingly, in August 1939 two Mark XIX guns were sent to each of these ports and, mounted on a specially designed concrete platform, installed in a coastal artillery role. The gun displayed at the Museum is one of the two despatched to East London. When, in 1940, standard coast defence guns were installed in that city, this piece and its companion were sent to Durban, where it remained in reserve for the rest of the war. At approximately the same time, standard coast defence guns were mounted at Port Elizabeth; and the two 6-in guns originally positioned there were transferred to Cape Town, to be installed in a similar temporary role at Apostle Battery, near Llandudnow.

A few 6-in Mark XIX guns were deployed in France during the early stages of World War II, but were rendered obsolete with the advent of the BL 5,5-in gun.

It is thus apparent that the guns exhibited in the Dan Pienaar Gun Park exemplify a priceless heritage of historic artillery pieces. The collection is unique in several important respects. First, several of the guns embody important milestones in the development of artillery. The $75 \mathrm{~mm}$ German gun, for example, illustrates the first design to facilitate 'variable recoil', as well as exemplifying the multi-purpose 'folding trail'. The British 13-pr field gun represents the very first British artillery piece utilized by the Royal Horse Artillery to be fitted with a bullet-proof shield. Second, one observes the variety of roles embodied in the collection; ranging from the horse gunner's arm (the $13 \mathrm{pr}$ ), to field artillery (the $15 \mathrm{pr}$ and $18 \mathrm{pr}$ ) and a specialized version of field guns, in the form of the $75 \mathrm{~mm}$ model 08 mountain gun. Third, the pieces displayed closely interact with and inform the history of South African artillery. Thus, the German 75 $\mathrm{mm}$ mountain gun's history is closely related to South African artillery in World War I; as also is the British 13-pr gun and the 15-pr, unique versions of the latter representing the very first South African anti-aircraft guns. 
Fourth, one observes the extremely wide compass of artillery history embraced by these guns; extending from the mid-1890s to the early years of World War II. Thus, the standard field guns which served both the Central and Allied powers on the Western Front, as well as the standard German howitzers deployed in this theatre, are contained in the display now housed in the Dan Pienaar Gun Park.

\section{CONCLUSION}

Ultimately, the central motivation underlying the creation of the new gun park is reverence for the memory of one of South Africa's most distinguished gunners, Maj Gen D H Pienaar, CB, DSO \& Bar. In his role of brigade and divisional commander, his career inevitably interacted with the histories of those units contained within the military formations that he commanded. Some of these formations have, inevitably, ceased to exist. However, many continue to retain their identity (albeit, in some cases with altered designations) to the present day. Thus, the Order of Battle of 1 SA Infantry Division, on 17 October 1942 (the date of the commencement of the 2 nd Battle of El Alamein) included the following infantry battalions whose existence has continued to the present day (to reiterate, in some instances with altered nomenclatures): I SA Infantry Brigade:- Regiment President Steyn; 2nd Regiment Botha (Divisional $H Q$ ); Royal Natal Carbineers; Duke of Edinburgh's Own Rifles; Transvaal Scottish: 2 SA Infantry Brigade:- Natal Mounted Rifles; Cape Town Highlanders; Middelandse Regiment; 3 SA Infantry Brigade:- Royal Durban Light Infantry, Imperial Light Horse; Rand Light Infantry. The critical artillery component comprised 1 Field Regiment (Cape Field Artillery) and 4 Field Regiment. Both gunner units continue to maintain their identity to the present day. The supporting services - the SA Engineer Corps, SA Corps of Signals and SA Medical Corps- obviously continue to serve the SADF at the present time. It is hoped that these units will be strongly supportive of the South African National Museum of Military History - as the home of this memorial to Maj Gen Pienaar - in its continuing efforts to perpetuate the memory of South Africa's fighting men of all races.

The most fitting conclusion to this article is undoubtedly formed by the following extract from Lt Gen Meiring's speech at the official opening:

'...l would like to congratulate the Chairman and the members of the Council of the South African National Museum of Military History for embarking on an ambitious long-term development of this Museum in spite of the financial constraints unfortunately imposed by the state and by the economy of the country. I wish you well with your endeavours and shall take note of future progress with interest. I would also like to stress that the South African Army fully supports the Museum in its efforts to improve its facilities and the scope of its exhibits. I am fully aware of the educational role the Museum plays in the community and of its importance to the South African Defence Force as a whole. As a former member of the Council of this Museum I am delighted to be here again and to see such an impressive display area and I am particularly pleased that tribute is to be paid to one of our best-known and admired military leaders. This gun park with its statue of Dan Pienaar and the wellpreserved guns is a permanent reminder of our military exploits and the sacrifices made by our men and women in uniform.

\footnotetext{
* Dr Monick is the Curator of Medals and Numismatics at the South African National Museum of Military History.
} 